\title{
Ku Protein
}

National Cancer Institute

\section{Source}

National Cancer Institute. Ku Protein. NCI Thesaurus. Code C17305.

A DNA damage repair complex that, with the 470-kDa DNA-dependent protein kinase catalytic subunit (DNA-PKCS) protein, is part of the DNA-dependent protein kinase. This protein complex is involved in $V(D)$ J recombination, nonhomologous end-joining DNA repair, and the recognition and repair of double-stranded DNA breaks. 